Article

\title{
A New Procedure for Deep Sea Mining Tailings Disposal
}

\author{
Wenbin Ma ${ }^{1, *}$, Dingena Schott ${ }^{1}$ and Gabriël Lodewijks ${ }^{2}$ \\ 1 Department of Maritime \& Transport Technology, Delft University of Technology, \\ 2628 CD Delft, The Netherlands; D.L.Schott@tudelft.nl \\ 2 School of Aviation, Faculty of Science, University of New South Wales, Sydney NSW 2052, Australia; \\ G.Lodewijks@unsw.edu.au \\ * Correspondence: W.Ma@tudelft.nl; Tel.: +31-152-781-728
}

Academic Editor: Glen Corder

Received: 3 February 2017; Accepted: 18 March 2017; Published: 23 March 2017

\begin{abstract}
Deep sea mining tailings disposal is a new environmental challenge related to water pollution, mineral crust waste handling, and ocean biology. The objective of this paper is to propose a new tailings disposal procedure for the deep sea mining industry. Through comparisons of the tailings disposal methods which exist in on-land mining and the coastal mining fields, a new tailings disposal procedure, i.e., the submarine-backfill-dam-reuse (SBDR) tailings disposal procedure, is proposed. It combines deep sea submarine tailings disposal, backfill disposal, tailings dam disposal, and tailings reuse disposal for the deep sea mining industry. Then, the analytic network process (ANP) method is utilized to evaluate the performances of different tailings disposal methods. The evaluation results of the ANP show that the new proposed tailings disposal procedure is the most suitable for the deep sea mining industry.
\end{abstract}

Keywords: analytic network process (ANP); deep sea mining; environmental challenge; SBDR tailings disposal procedure; waste handling

\section{Introduction}

As resources consumption continues to increase, the mining industry has become one of the most important economic activities in the modern world [1]. Tailings are the by-products of hard rock mining operations. They are removed from the valuable mineral ores after filtering and milling processes [2]. With the significant increase of the total global production rate, the enormous amount of tailings must be handled with a proper method. Additionally, the disposal of tailings is an integrated multi-disciplinary field related to biology, hydrology, topography, sustainable development, and environment protection [3].

With the gradual decrease of mineral reserves and varieties on land, deep sea mining (DSM) has been put forward by mining researchers since the 1960s [4]. The schematic diagram of a typical DSM system is shown in Figure 1 [5]. Due to the broad scope of influence of DSM tailings, an integrated cognitive system needs to be obtained to get a clear understanding of the challenges [6]. The differences between a DSM project and a terrestrial mining project can be described as follows. Firstly, the DSM operation is confined to a limited field, far away from the coast. The long distance from mine sites to harbors leads to expensive transportation when the tailings are transported to a tailings pond or on-land stack. Secondly, the range of activities and available areas of tailings treatment equipment are limited to the ship for DSM tailings disposal. Thirdly, the dissolved heavy metals from tailings can have a long lasting influence on the deep sea environment for up to 60 to 70 years. Fourthly, there is not sufficient knowledge on the potential values of benthic flora and fauna [2-7]. 


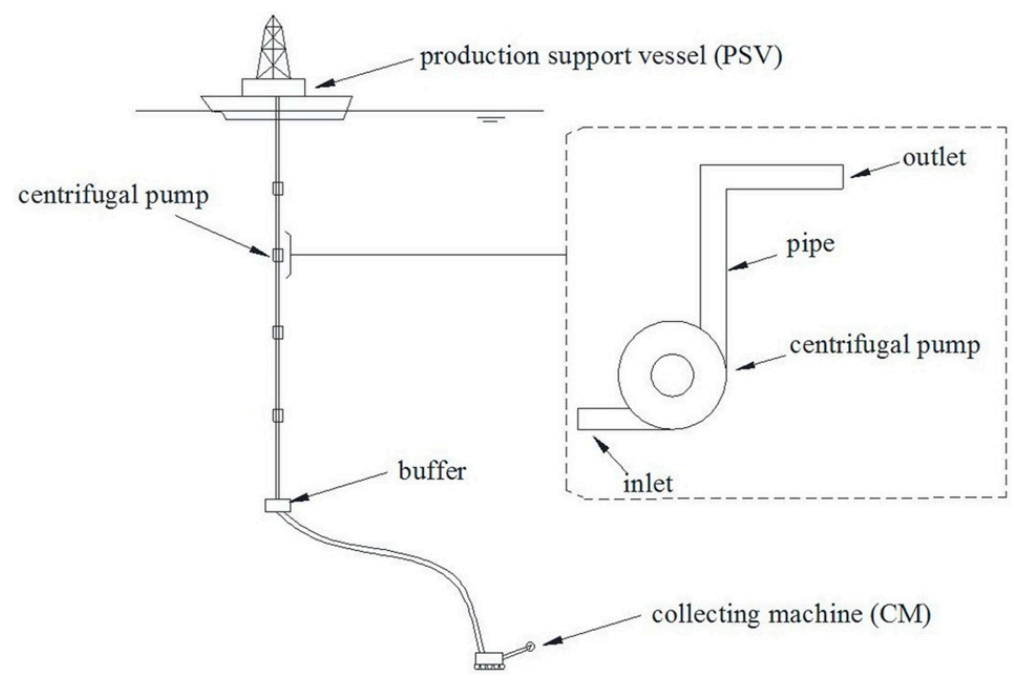

Figure 1. The schematic diagram of a typical deep sea mining (DSM) system.

\subsection{Tailings Disposal Methods Introduction}

The tailings disposal methods mainly consist of submarine tailings disposal, tailings dam disposal, backfill disposal, and tailings reuse disposal [8]. Submarine tailings disposal consists of surface submarine tailings disposal and deep sea submarine tailings disposal, depending on the depth of tailings discharge in the ocean. The tailings discharge depth of deep sea submarine tailings disposal is below 1000-1100 $\mathrm{m}[3,8]$. The tailings dam disposal is the most common disposal method with a long history. The tailings dam disposal often works with backfill disposal after tailings undergo paste and thickened stages [9].

For the DSM industry, the deep sea water transported to the ocean surface also belongs to mine tailings. The tailings water, after the filtering process of the mineral ores, contains a much higher concentration of heavy metals. For example, for the Navodari mine site, the tailings water contains cadmium up to $29 \mathrm{ppm}$, fluorine up to 105-207 ppm, sulphates up to 1100-1720 ppm, and phosphates up to $1270 \mathrm{ppm}$ [10]. The tailings water with a high concentration of heavy metals can significantly damage the habitat environment of plankton and benthic nekton, which can increase the concentration of heavy metals in fishes. Finally, human beings are affected by the heavy metals through the food chain [11].

The tailings disposal of the DSM industry can be more difficult because of its complex working environment. The tailings produced by the DSM industry are distributed all over the mineral transport process from seabed to ocean surface, then to a harbor. As in most DSM projects, mining sites are often located far away from the land. If, for a DSM project, a proper tailings disposal method cannot be selected, the tailings disposal expenditure can be huge. Furthermore, it is remarkable to consider that the tailings operation is influenced directly by the profitability of the mining operation and some other uncertainties, e.g., commodities price, fluctuations in operating and capital cost, geological properties and so on [12,13]. Additionally, the fragile deep ocean ecology can be easily affected by the contaminants contained in tailings.

\subsection{Evaluation Method Introduction}

After comparing the traditional tailings disposal methods, the analytic network process (ANP) is utilized to evaluate the performance of the different tailings disposal methods. The ANP is a strategy management method that analyzes decisions and actions on all levels in the objective research field [14]. The ANP was invented on the basis of the analytic hierarchy process (AHP) by considering the interdependences among the major criteria and the sub-criteria. In addition, the ANP divides different classifications of the evaluation criteria and the actors involved in the evaluation process $[13,14]$. 
The objective of this paper is to propose a new tailings disposal procedure for the DSM industry based on a comparison of the tailings disposal methods. A new tailings disposal procedure, i.e., the SBDR tailings disposal procedure, is proposed by the combination of deep sea submarine tailings disposal, backfill disposal, tailings dam disposal and tailings reuse disposal methods. Four different tailings disposal methods are firstly coupled together to process tailings from DSM projects. The research in this paper has filled a research gap in which there are insufficient theories and analysis results for DSM tailings disposal. In Section 2, different tailings disposals utilized on land and at the coastal sites are introduced and compared. Section 3 describes an innovated tailings disposal procedure derived from the existing tailings disposals. Section 4 addresses the evaluations of the different tailings disposals by the ANP method. Finally, in Section 5, conclusions of the conducted research are given.

\section{Tailings Disposal Methods}

The tailings disposal methods discussed in this section are submarine tailings disposal, tailings dam disposal, backfill disposal and tailings reuse disposal.

\subsection{Submarine Tailings Disposal (STD)}

Submarine tailings disposal has been utilized since 1938, with copper mine tailings from Chanaral, Chile, being poured into the ocean [15]. The working methodology of submarine tailings disposal is to dump tailings into seas through a channel or a pipe system [16]. The copper mine tailings in Chile with a high copper concentration of 6000-7000 $\mu \mathrm{g} / \mathrm{L}$, which is much higher than the present regulation of $2000 \mu \mathrm{g} / \mathrm{L}$, were discharged into the coastal Pacific Ocean [17]. Due to the long-term continuous tailings displacement, the copper mine tailings changed the geographical terrain around the tailings discharge outlet, see Figure 2 [3].

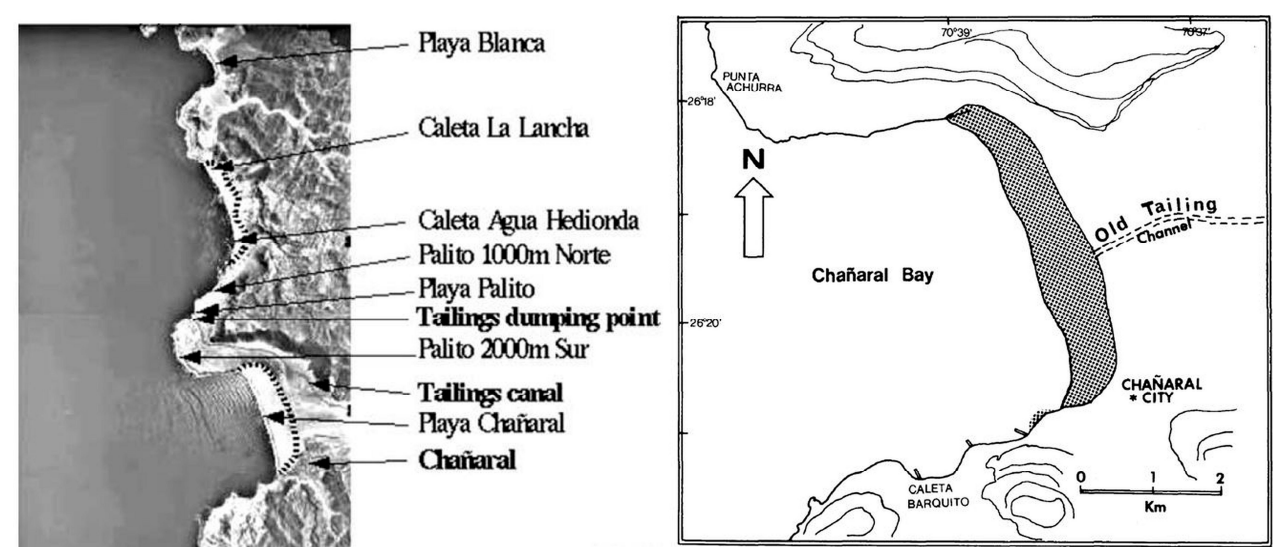

Figure 2. The global and the enlarged view of the tailings beach [3].

As the tailings discharge rate of submarine tailings disposal can be large, which ranges from 2000 ton/day to 30,000 ton/day, it is suppressed in many countries and districts due to its potential environmental threats [18]. For example, in United States, only Alaska is given an exemption to implement the surface submarine tailings disposal method by US Environmental Protection Agency [3], and in Chile, the tailings of its copper mine sites cannot be poured into the ocean, as determined by a famous lawsuit between the Village of Chañaral against Chilean National Copper Corporation (CODELCO) in 1989 [16]. Submarine tailings disposal is also forbidden in Canada and Australia [19].

Deep sea submarine tailings disposal is different from surface submarine tailings disposal in the discharge depth at which the tailings are disposed of in the ocean. Deep sea submarine tailings disposal is innovated from surface submarine tailings disposal, considering ocean turbidity, light penetration, alteration of the benthic habitat, and burial of the aquatic organisms [20]. Compared with surface 
submarine tailings disposal, deep sea submarine tailings disposal has a better performance on benthic habitat protection because of the shorter diffusion, mixing and sedimentation length of the discharged tailings [20]. Gideiri suggested that the depth at which tailings are discharged in deep sea submarine tailings disposal should be below $1100 \mathrm{~m}$, considering biological activity [21]. Nawab proposed that deep sea submarine tailings disposal should take place between $1000 \mathrm{~m}$ and $1100 \mathrm{~m}$, which considers both minimizing the effects on fauna and flora by the tailings depositions and avoiding re-deposition into the mineralized area [22]. Franks recommended that the tailings discharged into the mining voids can dramatically reduce the mining footprint in the deep sea ecosystem [8].

\subsection{Tailings Dam Disposal (TDD)}

Tailings dam disposal is described as an embankment structure to store mineral tailings, which can be used for tailings in solid, liquid, and solid-liquid phases [23]. Additionally, tailings dam disposal is regarded as the most widely used tailings disposal method. The direct influences of tailings dam disposal on the local environment consist of salinity/PH alteration and the potential mobility of toxic metals [24].

Although the application of tailings dam disposal is wide, some singular characteristics, such as extensive management operation, seismic liquefaction, rise of the phreatic surface, mass movement/slope instability, fluvial undermining, inadequate/insufficient beach or free board, piping/seepage, dam overtopping/overflowing, foundation failure, water level rise, unusual rainfall evert/period, insufficient perviousness of filter drain, and mine subsidence, can lead to far-reaching tailings dam failures [25]. In the United States, from 1917 to 1989, there were 185 tailings dam incidents, in which about $90 \%$ of the incidents happened in the active mines [24]. Furthermore, as the height of the tailings dam can reach $20-45 \mathrm{~m}$ and the biggest reservoir volume is almost up to $2.5 \times 10^{8}-3.5 \times 10^{8} \mathrm{~m}^{3}$, the consequences of the tailings dam failures on the economy, environment, and human beings safety can be immeasurable [26].

\subsection{Backfill Disposal (BD)}

The backfill disposal, also named paste backfill disposal, was proposed in the 1990s [27]. The working process of backfill disposal is to transfer traditional mill tailings or slurry tailings into paste tailings, which is beneficial in the aspects of mine reclamation and elimination of the adverse environmental effects of the discharged tailings [28]. The backfill materials consist of overburdens, waste rocks, deslimed and whole mill tailings, quarried and crushed aggregate, and metallurgical process tailings. Kesimal et al. proposed that the tailings mixed with the binder, such as the cement, can make it easier to achieve the desired rheological and strength characteristics of the paste tailings [28]. Franks proposed backfill disposal as an environmentally friendly tailings disposal method, which can lead to relatively high physical and chemical stability of the tailings [8]. The backfill disposal can also work with the other tailings disposals. For instance, since the second quarter of 2001, backfill disposal and tailings dam disposal have been utilized in Bulyanhulu gold mine in Tanzania, in which $25 \%$ of the paste tailings are dewatered, thickened, strengthened, and backfilled underground, and the remaining $75 \%$ of tailings are discharged on the surface [7].

\subsection{Tailings Reuse Disposal (TRD)}

As most mineral tailings are not utilized completely, after proper treatment, reuse and recycling processes, the valueless tailings can be transferred into other productions, producing some extra economic benefits. The central idea of tailings reuse disposal is to minimize the waste volume [29]. For tailings in the DSM industry, waste rocks and overburdens can be reused as the construction material for island construction; this has been the case in Korea, China, the Netherlands, and Japan [30]. The island or land reclamation utilizing the DSM tailings can undoubtedly decrease the influences on the deep sea ecosystem. However, reclamation engineering also has several environmental problems, such as an increase in the groundwater level of the places where tailings are reused. The tailings reuse 
disposal method is an innovative, new concept to tailings disposal in the DSM industry. For the tailings produced on land, tailings reuse disposal has been more thoroughly researched, such as in short-term and long-term experiments, the realistic test, the environmental effects analysis and so on [31].

\section{DSM Tailings Disposal}

\subsection{Tailings Disposal Distributions in the DSM Process}

In the working process of the DSM industry, a large amount of tailings are produced and tailings disposal which considers technology, economy, environment, and societal acceptance at the same time is quite necessary. Additionally, the tailings discharged in the DSM process have both short-term effects, e.g., seafloor destruction, and long-term effects, e.g., topography alteration; oxygen and heavy metal concentration; habitant alteration of the flora and the fauna [3]. The tailings in DSM are produced in two major parts: tailings produced at sea and tailings produced on land after further processing. This paper focuses on the tailings produced at sea, which include waste water, waste rocks, overburdens, benthic flora, and fauna. As the DSM project researched in this paper is transported by a pipe system, the most influential areas of DSM are located at the seabed and the ocean surface.

\subsection{Advantage and Disadvantage Analysis of the Reviewed Tailings Disposal Methods}

Table 1 depicts the advantages and disadvantages of deep sea submarine tailings disposal, backfill tailings disposal, tailings dam disposal, and tailings reuse disposal. In the history of tailings disposal, combining different kinds of tailings disposal methods already exists. For instance, in arid and semi-arid areas, tailings are stored in tailings dams firstly; undergoing natural evaporation and consolidation by hardener, the tailings with a high concentration of water can be transferred into tailings pastes; then, the tailings paste can be backfilled into the mining site to decrease the mining footprint [32].

Table 1. Advantages and disadvantages of the reviewed tailings disposal methods.

\begin{tabular}{|c|c|c|}
\hline Method & Advantages & Disadvantages \\
\hline $\begin{array}{c}\text { Deep sea } \\
\text { submarine } \\
\text { tailings disposal }\end{array}$ & $\begin{array}{l}\text { 1. Prevention of acid mine drainage. } \\
\text { 2. Geotechnically stable. } \\
\text { 3. Minimal land surface used. } \\
\text { 4. Short transport distance. } \\
\text { 5. Short-term maintenance. }\end{array}$ & $\begin{array}{l}\text { 1. Overlay the benthic organisms. } \\
\text { 2. Physical and geochemical } \\
\text { alteration of the seabed environment. } \\
\text { 3. Release contaminants into the sea. } \\
\text { 4. Bioaccumulation of heavy metals } \\
\text { through the food chain [16]. }\end{array}$ \\
\hline Backfill disposal & $\begin{array}{l}\text { 1. Short transport distance, making it cost effective [9]. } \\
\text { 2. Decrease the mine footprint [33]. } \\
\text { 3. Tailings are almost environmentally friendly [32]. } \\
\text { 4. Operation simplicity. } \\
\text { 5. Inhibit the oxidation [9]. }\end{array}$ & $\begin{array}{l}\text { 1. Short-term increase of the tailings } \\
\text { concentration in the nearby ocean area [9]. } \\
\text { 2. Overlay the benthic organism. } \\
\text { 3. Release the toxicity contaminants } \\
\text { into the sea [34]. }\end{array}$ \\
\hline $\begin{array}{l}\text { Tailings dam } \\
\text { disposal (paste) }\end{array}$ & $\begin{array}{l}\text { 1. Low preliminary investment. } \\
\text { 2. Decrease the waste water volume. } \\
\text { 3. Decrease the construction embankment materials. } \\
\text { 4. Operation simplicity }[7,35] \text {. }\end{array}$ & $\begin{array}{l}\text { 1. Ground water pollution. } \\
\text { 2. Long-term maintenance in the mining } \\
\text { process and even after the mining closure [24]. } \\
\text { 3. Erosion and sedimentation generate } \\
\text { acidic conditions [25]. } \\
\text { 4. Flexible to the nature hazards, e.g., } \\
\text { seismic and strong precipitation [8]. }\end{array}$ \\
\hline $\begin{array}{l}\text { Tailings reuse } \\
\text { disposal }\end{array}$ & $\begin{array}{l}\text { 1. Create new values. } \\
\text { 2. Decrease the environmental effects at the mining site [36]. }\end{array}$ & $\begin{array}{l}\text { 1. Environmental alteration at the tailings } \\
\text { reused site, e.g., PH, groundwater drainage, } \\
\text { heavy metals concentration, and the } \\
\text { surrounding organisms [29]. }\end{array}$ \\
\hline
\end{tabular}

\subsection{Tailings Disposal Method Suitable for the DSM Systems}

Through analyzing different tailings disposal methods and tailings distributions in the DSM process, it is noteworthy that utilizing only one tailings disposal method cannot fulfil the economic and environmental considerations at the same time [37]. Therefore, a new tailings disposal procedure, 
combining deep sea submarine tailings disposal, backfill disposal, tailings dam disposal and tailings reuse disposal methods is created: SBDR (submarine-backfill-dam-reuse disposal), see Figure 3.

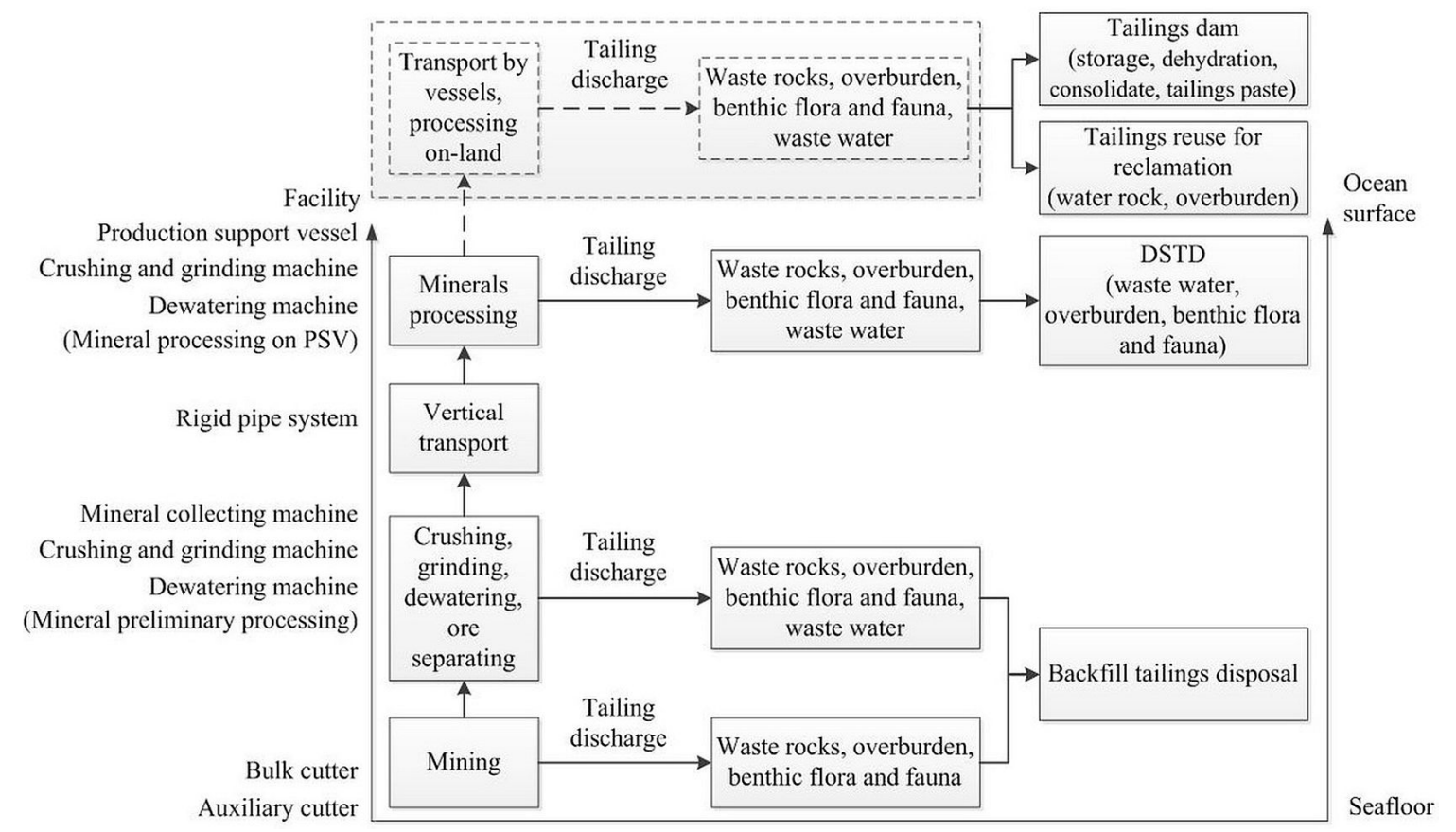

Figure 3. The schematic diagram of the SBDR tailings disposal procedure utilized in the deep sea mining industry.

For the tailings produced on the seabed, the backfill disposal is selected. Based on the application rule of backfill disposal, the tailings of overburdens, waste rocks, benthic flora and fauna are backfilled at the mine site to decrease the mining footprint. The backfill tailings are almost environmentally friendly, because the tailings do not undergo a long period of transport and processing processes [35]. Additionally, the proximity principle to discharge the tailings can greatly decrease the mine site footprint and the transport costs of the tailings [34]. For the tailings produced on the production support vessel (PSV), after the crushing, grinding, concentrated dewatering, and ore separating processes, the tailings belonging to the inert inorganic geological materials can be transported to a deep sea environment through a pipe system, which utilizes the deep sea submarine tailings disposal. Furthermore, the inert inorganic geological tailings can also be reused as land or island reclamation materials. For instance, in China, the tailings produced from on-land mining are reused to produce cement, hollow bricks, concrete, and glass [36]. Therefore, the waste tailings can also produce some extra economical values and compensate the expensive transport costs [38]. Although it is difficult to reuse all the materials in the mineral tailings, the reuse tailings disposal offers a promising method considering both the environment and economy. The tailings produced on the PSV, which are chemically active, organic, non-geological and concentered with water contaminants, e.g., heavy metal sedimentations, should be transported to a harbor to eliminate the enormous environmental effects in the sea. This kind of tailings should undergo storage; dehydration by evaporation; consolidation by gravity, and the reinforcement materials, e.g., cement to form the tailings paste through tailings dam disposal [39].

After comparing the advantages and disadvantages of deep sea submarine tailings disposal, backfill tailings disposal, tailings dam disposal, and tailings reuse disposal, as well as the analysis of how the SBDR tailings disposal procedure works, the advantages of SBDR tailings disposal can be summarized as follows: 
1. A higher degree of tailings utilization. The tailings at different engineering fields have different definitions. For instance, in Japan, the tailings and waste can be divided into different classifications: by-product, waste in law, municipal waste, and industrial waste. A high degree of tailings utilization also represents a more environmentally friendly tailings disposal system for the mine sites.

2. Extra economic value. The tailings are transferred from waste to products, e.g., cement and bituminous mixtures for land or island reclamation.

3. Reasonable operation costs. The tailings separation refinements can also produce an optimal operation plan for the tailings disposal. For instance, although tailings dam disposal needs only a small preliminary capital investment, the long-term operation costs and the long distance transport costs account for a big proportion of the total expenditure. On the contrary, deep sea submarine tailings disposal needs a large preliminary capital investment. However, its short-term maintenance costs and the transportation expenditure are much lower than tailings dam disposal for DSM tailings treatment [40].

The disadvantages of SBDR tailings disposal can be summarized as follows:

1. An effective working combination will be a problem. The SBDR tailings disposal procedure is innovated from the existing tailings disposal methods. It takes the DSM special working environment and different working conditions into consideration. Additionally, the tailings dam disposal utilized in the SBDR procedure is also a new tailings disposal method, which only exists in some special mining areas [29].

2. The utilization of different tailings disposal methods also represents a high preliminary capital investment. For instance, the working mechanism of the SBDR tailings disposal procedure should consist of a more sophisticated minerals separation system; a pipe system utilized to transport the tailings $1100 \mathrm{~m}$ below the ocean; vessels to hold and transport the active, organic, non-geological contaminants and tailings; the tailings dam; tailings dehydration and consolidation mechanisms; a tailings transformation machine transferring the wastes into the reused products.

3. Environmental effects on the site where the tailings are discharged and reused. For instance, the tailings discharged $1100 \mathrm{~m}$ below the ocean will increase the heavy metal concentrations there. Besides, although there is almost no upwelling in the deep sea [41], the fine particles of the tailings can also be dispersed by the plumes, influencing the surrounding ocean ecosystem. Additionally, if the tailings are used as construction materials for embankments or for island reclamation, the environment of the places where tailings are reused will be altered. The alterations consist of the $\mathrm{PH}$ and element concentrations of the surrounding groundwater and the ground soil, and the habitat of the vegetation and animals. Furthermore, the environmental alteration can also influence the fisheries nearby [42].

\section{Evaluation of Tailings Disposal Methods}

The evaluation systems for tailings disposal have been researched for a long time. For instance, Horsak et al. utilized the fuzzy set analysis method to evaluate the tailings disposal site and selected the evaluation criteria as follows: air quality, surface water quality, groundwater quality, ecology, aesthetic, demography, land use, transportation, emergency response, opposition [43]. Additionally, there is an evaluation system of tailings disposal which focuses on aesthetic, economic and colonization conditions. For the tailings dam evaluation system, the criteria consist of economic consideration, flood and earthquake design criteria, environmental design flood criteria, water cover, long-term stability of the tailings dam, the dam safety, and risk estimation. An evaluation system for the tailings backfill consists of three parts: stability, economic consideration, and durability [32]. Additionally, there are a few reasons for utilizing the ANP method to perform an evaluation. Firstly, the ANP method can deal with the interdependent relationships among different criteria. Secondly, the ANP method can cover all aspects which are related to tailings disposal and present a clear relationship structure of all criteria. 
Based on the existing evaluation system of different tailings disposal methods, the evaluation criteria for the DSM tailings disposal can be defined as follows: economic criteria (ECO) which consist of capital cost (CC), operation and maintenance cost (OM) and energy cost (EC); social acceptance (SA) criteria which consist of community support (CS), policy support (PS) and environmental groups (EG) support; technological criteria (TC) which consist of its efficiency (TE), availability, maturity (AM) and tailings disposal capacity (CAP); and environmental criteria (ENV) which consist of sound quality (SQ), ocean water quality (OW), fauna and flora protection (F \& F), groundwater quality (GQ), air quality (AQ) and land use quality (LU).

\subsection{Analytic Hierarchy Process (AHP)}

The AHP was invented by Saaty in the 1970s to solve the decision-making problem relating to multiple criteria. The application premise of the AHP is that the multi-criteria evaluation for decision-making are assumed to be independent of each other. The weights of different criteria are determined through the pairwise comparison matrix [13,14].

The acceptance of the pairwise comparison matrix depends on the consistency index $(C I)$ and consistency ratio $(C R)$. When $C R$ values are smaller than 0.10 , then the pairwise comparison matrixes are regarded to be acceptable [44]. The CI value is calculated as follows [13,14]:

$$
C I=\frac{\lambda_{\max }-n}{n-1}
$$

where $\lambda_{\max }$ is the maximum eigenvalue of the pairwise comparison matrix; $n$ is a dimension of the pairwise matrix. The $C R$ value is calculated as follows $[13,14]$ :

$$
C R=\frac{C I}{R I}
$$

where $R I$ is the random index, which depends on the number of the evaluation criteria [44]. However, in the evaluation system of tailings disposal, most of the multiple criteria cannot be completely independent completely of each other. Therefore, a further improved method-the ANP-is invented on the basis of the AHP to deal with the decision-making problem [45].

\subsection{Analytic Network Process (ANP)}

In the application of the ANP, the multi-criteria interdependency can be utilized to evaluate different tailings disposal methods to determine the most suitable tailings disposal method. The relationship of the different levels of criteria is shown in Figure 4 [46]. In Figure 4, there exist four different levels of the evaluation system. The first level is the objective of the ANP evaluation system. The second level consists of the major criteria including economic consideration, social acceptance, technological consideration, environmental consideration. The third level consists of the sub-criteria which are assumed to be independent of each other. The fourth level is evaluation subjects, which are the different tailings disposals including deep sea submarine tailings disposal (DSTD), tailings dam disposal (TDD), backfill disposal (BD), tailings reuse disposal (TRD), and the SBDR tailings disposal procedure. A priority sequence can be determined by the ANP method, and the tailings disposal method with the largest weight is the most suitable method for the DSM industry [46]. There are two hypothesizes for the ANP utilization: (a) the major criteria are assumed to be interdependent; (b). the sub-criteria are assumed to be independent of each other. 


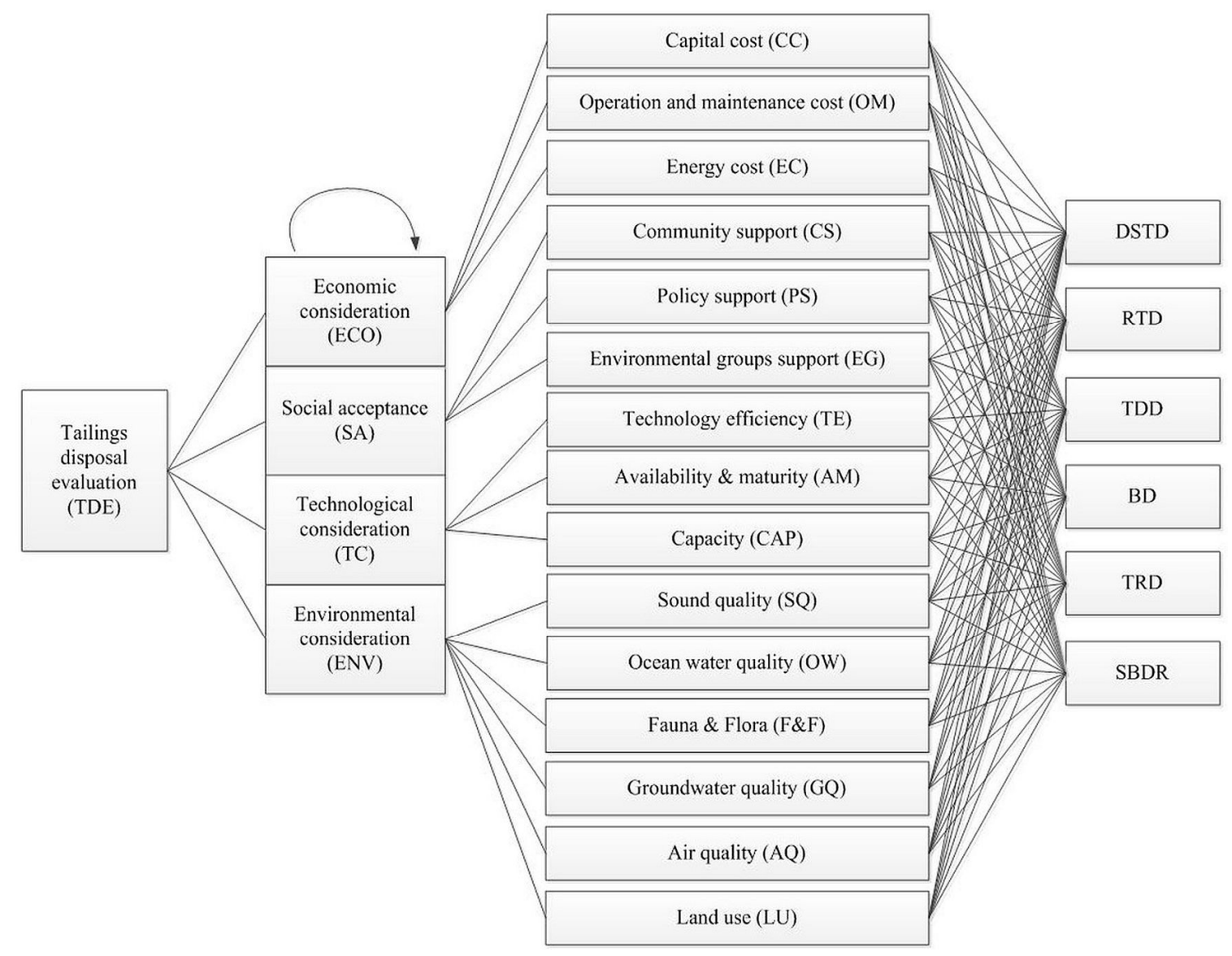

Figure 4. The analytic network process (ANP) model for the tailings disposal evaluation.

\subsection{The Questionnaire for the Data Collection}

Regarding the application of the ANP, the feedback of 17 experts in the fields of waste treatment, tailings disposal, marine environment pollution, and recycling of materials in marine structure construction was collected by a questionnaire. The objective of the questionnaire is to establish basic comparison matrixes among the major criteria and the sub-criteria. After the questionnaires were collected, firstly, the comparison matrixes are filtered based on the principle of the consistency ratio which needs to be smaller than 0.1. Secondly, the final weights of the criteria are calculated as the geometric mean weights, not the arithmetic mean weights, of all the qualified comparison matrixes [47].

\subsection{ANP Application on the DSM Tailings Disposal}

Firstly, the major criteria of the ECO, SA, TC, and ENV are assumed to be independent of each other. Depending on the pairwise comparison matrixes collected by the questionnaire and following the ANP weights calculation procedure, the weights of major criteria are shown with Equation (3).

$$
\mathrm{w}_{1}=\left[\begin{array}{c}
\mathrm{ECO} \\
\mathrm{SA} \\
\mathrm{TC} \\
\mathrm{ENV}
\end{array}\right]=\left[\begin{array}{l}
0.222 \\
0.263 \\
0.160 \\
0.355
\end{array}\right]
$$

Secondly, the inner connection between the different major criteria is determined by analyzing the influencing weights of each criterion on the other criteria by utilizing the pairwise comparison matrixes [14]. The inner connection among all the major criteria is shown in Figure 5. Depending on 
the comparison matrixes collected by the questionnaire, the weight vectors of ECO, SA, TC, and ENV on the other criteria are shown as follows:

$$
\left\{\begin{aligned}
\mathrm{w}_{2} & =\left[\begin{array}{lll}
0.297 & 0.269 & 0.434
\end{array}\right]^{\mathrm{T}} \\
\mathrm{w}_{3} & =\left[\begin{array}{lll}
0.309 & 0.221 & 0.470
\end{array}\right]^{\mathrm{T}} \\
\mathrm{w}_{4} & =\left[\begin{array}{lll}
0.350 & 0.291 & 0.359
\end{array}\right]^{\mathrm{T}} \\
\mathrm{w}_{5} & =\left[\begin{array}{lll}
0.298 & 0.313 & 0.389
\end{array}\right]^{\mathrm{T}}
\end{aligned}\right.
$$

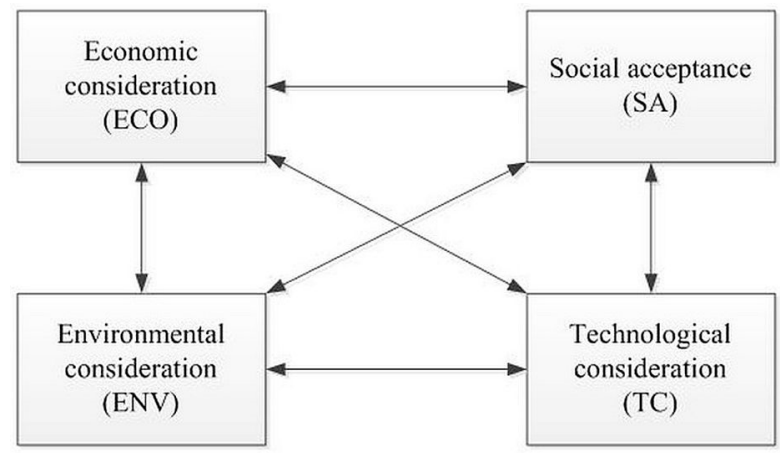

Figure 5. The inter-relationships between the major criteria.

Then, the inner connection matrix is determined based on Equation (4).

$$
\mathrm{w}_{\mathrm{i} \& \mathrm{c}}=\left[\begin{array}{cccc}
1.000 & 0.309 & 0.350 & 0.298 \\
0.297 & 1.000 & 0.291 & 0.313 \\
0.269 & 0.221 & 1.000 & 0.389 \\
0.434 & 0.470 & 0.359 & 1.000
\end{array}\right]
$$

Thirdly, the inner connected weights of all the major criteria are calculated with Equation (6).

$$
\mathrm{w}_{6}=\mathrm{w}_{\mathrm{i} \& \mathrm{c}} \times \mathrm{w}_{1}=\left[\begin{array}{c}
\mathrm{ECO} \\
\mathrm{SA} \\
\mathrm{TC} \\
\mathrm{ENV}
\end{array}\right]=\left[\begin{array}{llll}
1.000 & 0.309 & 0.350 & 0.298 \\
0.297 & 1.000 & 0.291 & 0.313 \\
0.269 & 0.221 & 1.000 & 0.389 \\
0.434 & 0.470 & 0.359 & 1.000
\end{array}\right] \times\left[\begin{array}{l}
0.222 \\
0.263 \\
0.160 \\
0.355
\end{array}\right]=\left[\begin{array}{l}
0.465 \\
0.487 \\
0.416 \\
0.632
\end{array}\right] \stackrel{\text { normalization }}{\rightarrow}\left[\begin{array}{l}
0.233 \\
0.243 \\
0.208 \\
0.316
\end{array}\right]
$$

Comparing Equations (3) and (6) before and after considering the inner connection among the major criteria, it is obvious to conclude that environment is regarded as the most important in tailings disposal. For the independent sub-criteria, the weights are determined following the same process as first step. The sub-criteria weight vectors, corresponding to the different major criteria, are shown with Equation (7).

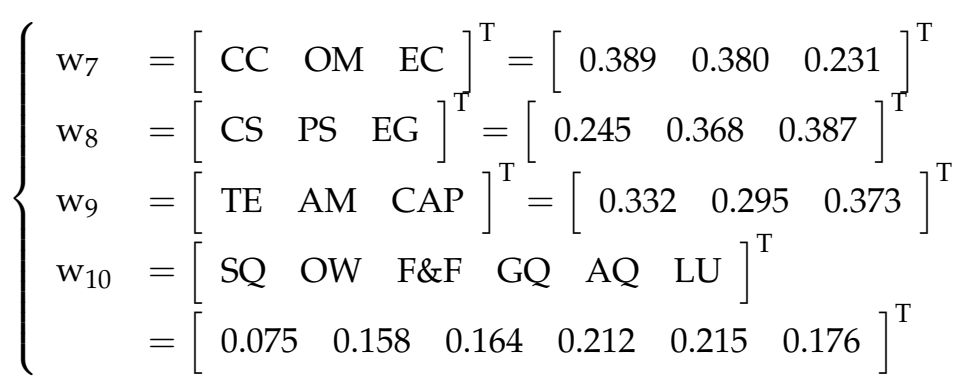


The final weights of the sub-criteria are calculated by multiplying the sub-criteria weights, i.e., Equation (7), by inner connected weights, i.e., Equation (6). The final weights of the sub-criteria are shown with Equation (8).

$$
\begin{aligned}
\mathrm{w}_{\mathrm{s} \& \mathrm{c}}= & {\left[\begin{array}{llllllllll}
\text { CC } & \text { OM } & \text { EC } & \text { CS } & \text { PS } & \text { EG } & \text { TE } & \text { AM } \\
\text { CAP } & \text { SQ } & \text { OW } & \text { F\&F } & \text { GQ } & \text { AQ } & \text { LU }
\end{array}\right]^{\mathrm{T}} } \\
= & {\left[\begin{array}{llllllllll}
0.091 & 0.089 & 0.054 & 0.060 & 0.089 & 0.094 & 0.069 & 0.061 \\
0.078 & 0.024 & 0.050 & 0.052 & 0.067 & 0.068 & 0.056
\end{array}\right]^{\mathrm{T}} }
\end{aligned}
$$

After determining the weights of all criteria, the next step deals with the priority degrees of the evaluated DSM tailings disposal methods, i.e., DSTD, RTD, TDD, BD, TRD, and SBDR, with respect to each criterion, which is shown with Equation (9) [14].

$$
\begin{aligned}
\mathrm{w}_{11}= & {\left[\begin{array}{c}
\text { DSTD } \\
\text { RTD } \\
\text { TDD } \\
\text { BD } \\
\text { TRD } \\
\text { SBDR }
\end{array}\right] } \\
& =\left[\begin{array}{lllllllllllllllll}
0.234 & 0.242 & 0.225 & 0.182 & 0.119 & 0.152 & 0.189 & 0.169 & 0.174 & 0.234 & 0.089 & 0.114 & 0.183 & 0.235 & 0.253 \\
0.113 & 0.092 & 0.103 & 0.040 & 0.052 & 0.059 & 0.116 & 0.215 & 0.185 & 0.076 & 0.270 & 0.282 & 0.068 & 0.135 & 0.098 \\
0.053 & 0.100 & 0.091 & 0.063 & 0.109 & 0.108 & 0.151 & 0.182 & 0.185 & 0.092 & 0.281 & 0.142 & 0.097 & 0.059 & 0.073 \\
0.333 & 0.327 & 0.262 & 0.091 & 0.075 & 0.082 & 0.262 & 0.198 & 0.228 & 0.240 & 0.035 & 0.086 & 0.287 & 0.243 & 0.241 \\
0.047 & 0.046 & 0.065 & 0.359 & 0.372 & 0.341 & 0.040 & 0.084 & 0.026 & 0.186 & 0.126 & 0.184 & 0.170 & 0.130 & 0.154 \\
0.220 & 0.193 & 0.254 & 0.265 & 0.273 & 0.258 & 0.242 & 0.152 & 0.202 & 0.172 & 0.199 & 0.192 & 0.195 & 0.198 & 0.181
\end{array}\right]
\end{aligned}
$$

Finally, the overall scores of each tailings disposal method are calculated by multiplying the priority degrees, i.e., Equation (9), by the final weights of the sub-criteria, Equation (8).

$$
\mathrm{w}_{12}=\left[\begin{array}{c}
\text { DSTD } \\
\text { RTD } \\
\text { TDD } \\
\text { BD } \\
\text { TRD } \\
\text { SBDR }
\end{array}\right]=\mathrm{w}_{11} \times \mathrm{w}_{\mathrm{s} \& \mathrm{c}}=\left[\begin{array}{l}
0.186 \\
0.121 \\
0.117 \\
0.203 \\
0.158 \\
0.218
\end{array}\right]
$$

The evaluation results through the ANP method show that the SBDR tailings disposal procedure is the most suitable method for the DSM industry. In the application of the ANP method, validation of the evaluation results is also very important. However, due to the ANP method dealing with the complex multi-criteria problem and the absence of the specific validation theory, the validation process will be more difficult [14]. The CR value can be utilized to validate the evaluation results, and it is applied to process the data derived from the questionnaire feedback [45]. Another validation method can be performed by specific DSM tailings disposal firms. Therefore, further systematic and scientific experiments should be done in cooperation with industrial companies undertaking tailings disposal in the DSM industry.

\section{Conclusions}

Based on the comparisons of the existing tailings disposal methods, a new tailings disposal procedure for DSM, i.e., the SBDR tailings disposal procedure, which combines DSTD, BD, TDD, and TRD tailings disposal methods systematically, is proposed. Based on the ANP evaluation results, the SBDR tailings disposal procedure is determined to be the best tailings disposal method for the DSM industry.

Future research may focus on the optimization and implementation of SBDR tailings disposal in the DSM industry. Additionally, the successful implementation of the SBDR tailings disposal 
procedure will also need to consider the sophisticated tailings separation technology and the optimal cutoff grade strategy, as well as considering stockpiling which can influence the generation rate of tailings significantly $[48,49]$.

Acknowledgments: This research is supported by the China Scholarship Council under grant 201506950007.

Author Contributions: Wenbin Ma, Dingena Schott and Gabriël Lodewijks worked together to propose a new tailings disposal procedure special for the DSM industry, and analyzed the data and approved the manuscript.

Conflicts of Interest: The authors declare no conflict of interest.

\section{References}

1. Bury, J. Mining Mountains: Neoliberalism, land tenure, livelihoods, and the new Peruvian mining industry in Cajamarca. Environ. Plan. A 2005, 37, 221-239. [CrossRef]

2. Kline, E.R.; Stekoll, M.S. Colonization of mine tailings by marine invertebrates. Mar. Environ. Res. 2001, 51, 301-325. [CrossRef]

3. Lee, M.R.; Correa, J.A. Effects of copper mine tailings disposal on littoral meiofaunal assemblages in the Atacama region of northern Chile. Mar. Environ. Res. 2005, 59, 1-18. [CrossRef] [PubMed]

4. Mero, J.L. The Mineral Resources of the Sea; Elsevier: Amsterdam, The Netherlands, 1965.

5. Ma, W.; Schott, D.; Lodewijks, G. Continuous line bucket lifting versus pipe lifting. J. Offshore Mech. Arct. Eng. 2017.

6. Sharma, R. Deep-sea mining: Economic, technical, technological, and environmental considerations for sustainable development. Mar. Technol. Soc. J. 2011, 45, 28-41. [CrossRef]

7. Theriault, J.; Frostiak, J.; Welch, D. Surface disposal of paste tailings at the Bulyanhulu gold mine, Tanzania. In Proceedings of the Sudbury 2003 Mining and the Environment Conference, Sudbury, ON, Canada, 25-28 May 2003; pp. 265-269.

8. Franks, D.M.; Boger, D.V.; Côte, C.M.; Mulligan, D.R. Sustainable development principles for the disposal of mining and mineral processing wastes. Resour. Policy 2011, 36, 114-122. [CrossRef]

9. Newman, P.; White, R.; Cadden, A. Paste, the future of tailings disposal. In Proceedings of the 2nd International Conference on Mining and the Environment, Skelleftea, Sweden, 25 June-1 July 2001; pp. 594-603.

10. Komnitsas, K.; Kontopoulos, A.; Lazar, I.; Cambridge, M. Risk assessment and proposed remedial actions in coastal tailings disposal sites in Romania. Miner. Eng. 1998, 11, 1179-1190. [CrossRef]

11. Edinger, E.N.; Siregar, P.R.; Blackwood, G.M. Heavy metal concentrations in shallow marine sediments affected by submarine tailings disposal and artisanal gold mining, Buyat-Ratototok district, North Sulawesi, Indonesia. Environ. Geol. 2007, 52, 701-714. [CrossRef]

12. Zhang, K.; Kleit, A.N.; Nieto, A. An economics strategy for criticality-Application to rare earth element Yttrium in new lighting technology and its sustainable availability. Renew. Sustain. Energy Rev. 2017. [CrossRef]

13. Zhang, K.; Nieto, A.; Kleit, A.N. The real option value of mining operations using mean-reverting commodity prices. Miner. Eng. 2015, 28, 11-22. [CrossRef]

14. Yüksel, İ.; Dagdeviren, M. Using the analytic network process (ANP) in a SWOT analysis-A case study for a textile firm. Inf. Sci. 2007, 177, 3364-3382. [CrossRef]

15. Castilla, J.C. Environmental impact in sandy beaches of copper mine tailings at Chañaral, Chile. Mar. Pollut. Bull. 1983, 14, 459-464. [CrossRef]

16. Dold, B. Submarine tailings disposal (STD)—A review. Minerals 2014, 4, 642-666. [CrossRef]

17. Castilla, J.C. Copper mine tailing disposal in northern Chile rocky shores: Enteromorpha compressa (Chlorophyta) as a sentinel species. Environ. Monit. Assess. 1996, 40, 171-184. [CrossRef] [PubMed]

18. Dauvin, J.C. Towards an impact assessment of bauxite red mud waste on the knowledge of the structure and functions of bathyal ecosystems: The example of the Cassidaigne canyon (north-western Mediterranean Sea). Mar. Pollut. Bull. 2010, 60, 197-206. [CrossRef] [PubMed]

19. McKinnon, E. The environmental effects of mining waste disposal at Lihir Gold Mine, Papua New Guinea. J. Rural Remote Environ. Health 2002, 1, 40-50. 
20. Findikakis, A.N.; Law, A.W. Marine tailings disposal simulation. J. Hydraul. Eng. 1998, 124, 370-383. [CrossRef]

21. Gideiri, Y.B.A. Impacts of mining on central Red Sea environment. Deep Sea Res. Part A Oceanogr. Res. Pap. 1984, 31, 823-828. [CrossRef]

22. Nawab, Z.A. Red Sea mining: A new era. Oceanogr. Res. Pap. 1984, 31, 813-822. [CrossRef]

23. Fourie, A.B.; Papageorgiou, G. Defining an appropriate steady state line for Merriespruit gold tailings. Can. Geotech. J. 2001, 38, 695-706. [CrossRef]

24. Macklin, M.G.; Brewer, P.A.; Hudson-Edwards, K.A.; Bird, G.; Coulthard, T.J.; Dennis, I.A.; Turner, J.N. A geomorphological approach to the management of rivers contaminated by metal mining. Geomorphology 2006, 79, 423-447. [CrossRef]

25. Rico, M.; Benito, G.; Salgueiro, A.R.; Díez-Herrero, A.; Pereira, H.G. Reported tailings dam failures: A review of the European incidents in the worldwide context. J. Hazard. Mater. 2008, 152, 846-852. [CrossRef] [PubMed]

26. Van Niekerk, H.J.; Viljoen, M.J. Causes and consequences of the Merriespruit and other tailings-dam failures. Land Degrad. Dev. 2005, 16, 201-212. [CrossRef]

27. Nasir, O.; Fall, M. Coupling binder hydration, temperature and compressive strength development of underground cemented paste backfill at early ages. Tunn. Undergr. Space Technol. 2010, 25, 9-20. [CrossRef]

28. Kesimal, A.; Yilmaz, E.; Ercikdi, B. Evaluation of paste backfill mixtures consisting of sulphide-rich mill tailings and varying cement contents. Cem. Concr. Res. 2004, 34, 1817-1822. [CrossRef]

29. Kamon, M.; Hartlén, J.; Katsumi, T. Reuse of waste and its environmental impact. In Proceedings of the ISRM International Symposium, Melbourne, Australia, 19-24 November 2000; pp. 1095-1123.

30. Suzuki, T. Economic and geographic backgrounds of land reclamation in Japanese ports. Mar. Pollut. Bull. 2003, 47, 226-229. [CrossRef]

31. Miao, Z.; Marrs, R. Ecological restoration and land reclamation in open-cast mines in Shanxi Province, China. J. Environ. Manag. 2000, 59, 205-215. [CrossRef]

32. Simms, P.; Grabinsky, M.; Zhan, G. Modelling evaporation of paste tailings from the Bulyanhulu mine. Can. Geotech. J. 2007, 44, 1417-1432. [CrossRef]

33. Kim, Y.S.; Lim, H.S.; Park, J.W. Comparison of Land Farming and Chemical Oxidation based on Environmental Footprint Analysis. J. Soil Groundw. Environ. 2015, 20, 7-14. [CrossRef]

34. Ercikdi, B.; Cihangir, F.; Kesimal, A.; Deveci, H.; Alp, İ. Utilization of industrial waste products as pozzolanic material in cemented paste backfill of high sulphide mill tailings. J. Hazard. Mater. 2009, 168, 848-856. [CrossRef] [PubMed]

35. Fall, M.; Célestin, J.C.; Pokharel, M.; Touré, M. A contribution to understanding the effects of curing temperature on the mechanical properties of mine cemented tailings backfill. Eng. Geol. 2010, 114, 397-413. [CrossRef]

36. Bian, Z.; Miao, X.; Lei, S.; Chen, S.E.; Wang, W.; Struthers, S. The challenges of reusing mining and mineral-processing wastes. Science 2012, 337, 702-703. [CrossRef] [PubMed]

37. Mendez, M.O.; Maier, R.M. Phytostabilization of mine tailings in arid and semiarid environments-an emerging remediation technology. Environ. Health Perspect. 2008, 116, 278. [CrossRef] [PubMed]

38. Desbarats, A.J.; Dirom, G.C. Temporal variation in discharge chemistry and portal flow from the 8-level adit, Lynx Mine, Myra Falls Operations, Vancouver Island, British Columbia. Environ. Geol. 2005, 47, 445-456. [CrossRef]

39. Sjödahl, P.; Dahlin, T.; Johansson, S. Using resistivity measurements for dam safety evaluation at Enemossen tailings dam in southern Sweden. Environ. Geol. 2005, 49, 267-273. [CrossRef]

40. Ellis, D.V.; Robertson, J.D. Underwater placement of mine tailings: Case examples and principles. In Environmental Impacts of Mining Activities; Springer: Berlin/Heidelberg, Germany, 1999; pp. 123-141.

41. Halliwell, G.R. Evaluation of vertical coordinate and vertical mixing algorithms in the HYbrid-Coordinate Ocean Model (HYCOM). Ocean Model. 2004, 7, 285-322. [CrossRef]

42. Miao, F.F.; Si, W.T.; Liu, J.M.; Wang, J.Y.; Zhang, X.F.; Cai, L. Study on oxidative damage and DNA damage in Misgurnus anguillicaudatas caused by the tailing lake seepage. Guangdong Agric. Sci. 2012, 38, 162-164.

43. Horsak, R.D.; Damico, S.A. Selection and evaluation of hazardous waste disposal sites using fuzzy set analysis. J. Air Pollut. Control Assoc. 1985, 35, 1081-1085. [CrossRef] 
44. Contreras, F.; Hanaki, K.; Aramaki, T.; Connors, S. Application of analytical hierarchy process to analyze stakeholders preferences for municipal solid waste management plans, Boston, USA. Resour. Conserv. Recycl. 2008, 52, 979-991. [CrossRef]

45. Saaty, T.L. The analytic network process. Iran. J. Oper. Res. 2008, 1, 1-27.

46. Khan, S.; Faisal, M.N. An analytic network process model for municipal solid waste disposal options. Waste Manag. 2008, 28, 1500-1508. [CrossRef] [PubMed]

47. Saaty, T.L. Decision making with the analytic hierarchy process. Int. J. Serv. Sci. 2008, 1, 83-98. [CrossRef]

48. Zhang, K.; Kleit, A.N. Mining rate optimization considering the stockpiling: A theoretical economics and real option model. Resour. Policy 2016, 47, 87-94. [CrossRef]

49. Nieto, A.; Zhang, K.Y. Cutoff grade economic strategy for byproduct mineral commodity operation: Rare earth case study. Min. Technol. 2013, 122, 166-171. [CrossRef]

2017 by the authors. Licensee MDPI, Basel, Switzerland. This article is an open access article distributed under the terms and conditions of the Creative Commons Attribution (CC BY) license (http://creativecommons.org/licenses/by/4.0/). 